\title{
EFFECT OF CASEIN TABLET MADE FROM GOAT MILK YOGURT ON LIVER HISTOPATHOLOGICAL PROFILE, DIOXIN RESIDUE, AND MALONDIALDEHYDE LEVEL IN BROILER EXPOSED TO 2,3,7,8-TETRACHLORODIBENZO-P-DIOXIN
}

\author{
Nur Aeni ${ }^{1)}$, Arie Srihardyastutie ${ }^{1)}$, Chanif Mahdi ${ }^{1)^{*}}$ \\ 1) Department of Chemistry, Faculty of Mathematics and Natural Sciences, Brawijaya University, Jl. \\ Veteran, Ketawanggede, Kec. Lowokwaru, Malang City, East Java, Indonesia, 65145 \\ Email: chanif@ub.ac.id
}

Submitted 8 May 2020; Accepted 13 July 2020

\begin{abstract}
2,3,7,8-Tetrachlorodibenzo-p-dioxin (TCDD) is a toxic compound of organic pollutants that is very persistent in the environment. This compound can accumulate in the body through contaminated food and can cause various adverse effects on human health. The purpose of this study was to observe the effect of casein tablets made from goat milk yogurt on Liver histopathological profile, residual TCDD and malondialdehyde (MDA) levels in broiler chicken exposed to $50 \mathrm{ng} / \mathrm{mL}$ TCDD. A total of 18 male broiler chickens aged 3 weeks were used in this study and were divided into 3 experimental groups based on a completely randomized design (CRD): 1 (negative control group), 2 (positive control group), 3 (therapeutic group) which were administered by $750 \mathrm{mg}$ of casein from goat milk yogurt for 21 days. TCDD residue and MDA levels in the liver were measured using a UV-Vis spectrophotometer and thiobarbituric acid reactive substances test, respectively. The liver histopathological profile was observed using hematoxylin-eosin staining. The results showed that the administration of casein tablets decreased the level of TCDD residue and MDA by $5.75 \%$ and $43.74 \%$, respectively. Moreover, the liver histopathological profile of the therapeutic group was better than that of the positive control group. It is suggested that casein tablet made from goat milk yogurt possesses anti-dioxin and antioxidant capacities.
\end{abstract}

Keywords: Casein product; goat milk yogurt; dioxin; MDA; histopathology 


\section{INTRODUCTION}

Animal food products are important contributors to humans as sources of animal protein, but 2,3,7,8-tetrachlorodibenzo-pdioxin (TCDD) and other types of dioxins exist in animal products and feed caused by environmental pollution from combustion, industrial waste, factory smoke, and vehicle pollution, and pesticides (Hayward and Bolger 2005; Kan and Meijer 2007) Dioxin compounds can enter the food chain and the body of living things. In humans, various extreme health effects have been linked to high exposure to dioxin compounds such as TCDD, which can result in disability and retardation of fetal and infant growth, reproductive disorders, chloracne, hormonal dysfunction, mood changes, reduced mental performance, diabetes, changes in white blood cells, tooth defects, endometriosis and the biggest effect caused by dioxin compounds is cancer. Thus, it is necessary to overcome free radicals that cause oxidative stress caused by exposure to dioxin compounds with food products that contain antioxidants (Pemberthy et al., 2016).

Casein goat milk yogurt is one of the food products having antioxidant capacity. Casein is a relatively short type of bioactive peptide that contains about 2-20 amino acids that can function as antioxidants, antiinflammatory, antihypertensive, antimicrobial, and anticancer properties which have a potential role in maintaining the health of the human body (Neha et al., 2012; Bamdad et al., 2017). Antioxidants can prevent chronic disease such as cardiovascular disease and cancer due to oxidative stress, and abnormal inflammatory response. Peptide intake from natural foods can delay the onset of disease by reducing oxidative damage and proinflammatory responses (Nuttal et al., 1999; Geronikaki and Gavalas., 2006) Among other animal food sources, milk protein is considered to be very nutritious and has a food component with a balanced composition of essential amino acids, and has also been reported as a good source of bioactive components (Bamdad et al., 2017).

In goat milk there is a casein complex polymorphism, casein content in goat milk represents $74 \%$ of total milk protein, whey protein amount is almost $17 \%$ and the proportion of non-protein nitrogen compounds is $9 \%$. Genetic polymorphism and casein frequency in goat milk populations have higher casein micelles than cow milk which explains better digestibility of goat milk and milk products than cow's milk (Verruck et al., 2019). Of the total milk protein casein accounts for $80 \%$, mainly from $\alpha \mathrm{S} 1 \quad \sim 40 \%$ of total casein), $\alpha \mathrm{S} 2(\sim 10 \%$ of total casein), $\beta$ ( $\sim 35 \%$ of total casein), and $\kappa(\sim 5 \%$ of total casein) casein sub-unit. Thus, casein phosphopeptides derived from gastrointestinal and commercial proteases can act as multifunctional bioactive peptides (Bamdad et al., 2017). The number of casein benefits of goat milk yogurt for body health and as a multifunctional bioactive peptide in reducing the number of free radicals, so in this research used a product casein yogurt goat milk to see residual levels of TCDD, MDA, and histopathological feature.

\section{MATERIALS AND METHODS}

This research was conducted at Karang Ploso Animal Farm, Biochemistry Laboratory of the Faculty of Mathematics and Natural Sciences, UPT Instrument

\footnotetext{
*Corresponding author:

Chanif Mahdi

Email: chanif@ub.ac.id

Department of Chemistry, Faculty of Mathematics and Natural Sciences, Brawijaya University, Jl. Veteran, Ketawanggede, Kec. Lowokwaru, Malang City, East Java, Indonesia, 65145
}

How to cite:

Aeni, N., Srihardyastutie, A., \% Mahdi, C. (2020). Effect of Casein Tablet Made from Goat Milk Yogurt on Liver Histopathological Profile, Dioxin Residue, and Malondialdehyde level in Broiler Exposed to 2,3,7,8-Tetrachlorodibenzo-P-Dioxin. Jurnal Ilmu dan Teknologi Hasil Ternak, 15 (3), 131-141 
Laboratory of the Department of Chemistry, and Pathology Laboratory of the Faculty of Medicine, Universitas Brawijaya Malang from November 2019 to March 2020. This research use Broiler (CP707) male Cobb strain, standard feed (7501B), chicken coops, feeding and drinking animals, sonde devices, scales, blenders, plastic wrap, hot plates, vortex (Maxi Mix Thermolyne), water bath, watch glass, glass preparation, mortar, separating funnel, refrigerator, aluminum foil, surgical instrument, scissors, clamp, micropipette, Eppendorf centrifuge, magnetic stirrer, LC-4K II centrifuge, light microscope (Olympus BX51), UV-Vis Spectrophotometry (UV-1601 Shimadzu), UV-Vis (Genesys-20), object-glass, cover glass, a place for staining, and paraffin cassettes. The material used in this study is standard solution $\quad(2,3,7,8$ Tetrachlorodibenzo-p-dioxin (TCDD), physiological $\mathrm{NaCl}$, filter paper, toluene pa (Merck), technical toluene, corn oil, a standard solution of malondialdehyde (TLC) MDA), Phosphate Buffer Saline (pH 7), $10 \%$ formalin, $1 \mathrm{~N} \mathrm{HCl}, 10 \%$ TCA, $1 \%$ Na-TBA, hematoxylin-eosin (HE) coloring, $95 \%$ ethanol, $90 \%, 80 \%$ and $70 \%$, xylol, paraffin, and distilled water.

\section{Conventional Casein $\quad$ Tablet Manufacturing}

The method used in making casein tablets is wet granulation. By preparing tools and materials, the composition of ingredients is needed in weigh according to calculations. Then the gelatin is dissolved in hot water. Ingredients such as casein, collidon 30, collidon $\mathrm{Cl}$, and lactose are the deep phases mixed for 15 min. After mixing $5 \mathrm{~mL}$ of gelatin is dropped to form a solid mass. Then sifted using a mesh No. 18 sieve to get the same granule size. Granules produced from the sieve are put into the oven for $2 \mathrm{~d}$.

The external phase material was mixed magnesium stearate and aerosol. Then the inner and outer phase ingredients are mixed for $10 \mathrm{~min}$ and sifted using mesh No. 18. Weighed $500 \mathrm{mg}$ per tablet in parchment. Pressing the tablet using a press machine. Then an evaluation of the results of casein tablet products was carried out by calculating the uniformity of weights and sizes, testing the friability and fictionality of tablets by using a friabilator at a speed of $25 \mathrm{rpm}$ for $4 \mathrm{~min}$ to determine the fragility of tablets. Then disintegration to determine the disintegration time of the tablet by simulating a gastric solution (gastric fluid) that is as many as 6 tablets put in Eppendorf tube, then up and down in a medium of water at $37^{\circ} \mathrm{C}$. Crush time is calculated based on the most recently destroyed tablet. Crush time requirements for non-coated tablets are less than $30 \mathrm{~min}$. The composition of Casein Tablets can be seen in Table 1 below:

Table 1. Composition of Casein Tablets

\begin{tabular}{cc}
\hline Component & Concentration \\
\hline Casein Goat Milk Yogurt & $250 \mathrm{mg}$ \\
Collidon 30 & $600 \mathrm{mg}$ \\
Collidon Cl & $350 \mathrm{mg}$ \\
Lactose & $9300 \mathrm{mg}$ \\
Aerosil & $200 \mathrm{mg}$ \\
Magnesium Stearic & $200 \mathrm{mg}$ \\
Gelatin & $5 \%$ \\
\hline
\end{tabular}

\section{Preparation of Animal Model}

The preparation of experimental animals was carried out based on ethical approval that was approved by the UB research ethics committee with ethics approval no. 1189-KEP-UB. Male broiler chickens are divided into 3 treatment groups with a population of 6 animals each/cage. Before the treatment is carried out, the chickens are kept and adapted first to the 
condition of the cage and given ad-libitum feed and drink. Male broiler chickens aged $3 \mathrm{wk}$ were treated in a group of experimental animals namely group I (negative control) which were only given standard feed and drink. Group II (positive control) chickens exposed to TCDD $50 \mathrm{ng} / \mathrm{mL} / \mathrm{kg}$ of feed for $21 \mathrm{~d}$. Group III (therapeutic group) chickens exposed to TCDD $50 \mathrm{ng} / \mathrm{mL} / \mathrm{kg}$ of feed and treated with $750 \mathrm{mg}$ of casein from goat milk yogurt casein tablet products or 3 tablets of casein goat milk yogurt for $21 \mathrm{~d}$ by oral gavage. Then surgery is taken to take chicken liver, part of the liver is put in $10 \%$ formalin solution to make histopathological features and some others are wrapped in plastic clips, then stored in the refrigerator $\left(-20^{\circ} \mathrm{C}\right)$ for $7 \mathrm{~d}$ as a sample for determining TCDD residue levels and samples for determining levels MDA

\section{Measurement of TCDD Residual Levels in the Liver}

A standard curve of 2,3,7,8Tetrachlorodibenzo-p-dioxin (TCDD) was made. Furthermore, chicken liver samples were cut into small pieces, mashed using a mortar, weighed as much as $5 \mathrm{~g}$, added $10 \mathrm{~mL}$ of technical toluene solvent, covered with plastic wrap and aluminum foil, then stirred and homogenized using a magnetic stirrer for $2 \mathrm{~h}$ at speed of $8000 \mathrm{rpm}$. Then allowed to stand for $3 \mathrm{~h}$, filtered using Whatman 41 filter paper, then the residual results are extracted again in the same way. The results of the sample filtrate from 2 times the extraction were taken to measure the TCDD residue levels using UV spectrophotometry at a wavelength of $305 \mathrm{~nm}$. This method is based on references from (Binh et al., 2014) with modifications.

\section{Determination of Malondialdehyde (MDA) Levels in Liver}

Malondialdehyde (MDA) calibration curves were made. Furthermore, chicken liver samples are cut into small pieces, mashed using a mortar, then weighed as much as $0.2 \mathrm{~g}$, put into Eppendorf centrifuge added $1 \mathrm{~mL}$ Physiological $\mathrm{NaCl}$.
Centrifuged for $20 \mathrm{~min}$ at a speed of $8000 \mathrm{rpm}$, supernatant piped as much as $200 \mu \mathrm{L}$ into the test tube. Then added $500 \mu \mathrm{L}$ of distilled water, $200 \mu \mathrm{L}$ of TCA $10 \%, 500 \mu \mathrm{L}$ of $\mathrm{HCl} 1 \mathrm{~N}, 200 \mu \mathrm{L}$ of NaTBA $1 \%$, homogenized, then heated in a water bath at $100^{\circ} \mathrm{C}$ for $20 \mathrm{~min}$. Lifted and cooled at room temperature, then centrifuged for $10 \mathrm{~min}$ at a speed of $3000 \mathrm{rpm}$, pipette and absorbance measured using a UV-Vis spectrophotometry at a maximum wavelength of $532 \mathrm{~nm}$ (Singh et al., 2002).

\section{Preparation and Reading of Histopathological Illustration}

Histopathological of the chicken liver using $\mathrm{HE}$ staining with fixation process by inserting it in $10 \%$ formalin solution, dehydration stage using ethanol with concentrated concentrations of $70 \%$ for $24 \mathrm{~h}, 80 \%$ ethanol for $2 \mathrm{~h}, 90 \%, 95 \%$ and absolute ethanol for $20 \mathrm{~min}$. Then purification is done by soaking the organs in xylol I solution for $20 \mathrm{~min}$ and xylol II solution for $30 \mathrm{~min}$. Then the infiltration and embedding steps were carried out using liquid paraffin in the incubator at a temperature of $58^{\circ} \mathrm{C}-60^{\circ} \mathrm{C}$. Next, the cutting is done by clamping the mold in the microtome, and the tissue is cut with a thickness of $5 \mu \mathrm{m}$. The preparations were stored in an incubator at a temperature of $38^{\circ} \mathrm{C}-40^{\circ} \mathrm{C}$ for $24 \mathrm{~h}$, then deparaffinated ith xylol I and II solutions, rehydrated with 95\% ethanol, 90\%, 80\%, 70\% and washed with running water, then stained HE. Then the histopathological preparations are read by scanning the liver using a light microscope at magnifications of $100 \times$, $200 \times$, and $400 \times$ displayed on the monitor screen. This method is based on from (Swarayana et al., 2012) with modifications.

\section{Data Analysis}

Data analysis was performed quantitatively using the Analysis of Variance (ANOVA) statistical test using Microsoft Office Excel and SPPS 16.0 software for windows. And continued with 
the Tukey Honestly Significant Difference (HSD) test $\alpha=0.05 \%$. And data analysis of liver histopathology overview was done descriptively.

\section{RESULTS AND DISCUSSION}

\section{Effect of Casein Tablet Made from Goat Milk Yogurt on Dioxin Residue Level in Broiler Liver Exposed to 2,3,7,8- Tetrachlorodibenzo-p-dioxin}

The results of making a standard curve obtained by the equation $\mathrm{y}=1.69+$ 0.0408 with a value of $\mathrm{R} 2=0.9806$. The ANOVA statistical analysis results followed by the HSD Tukey test with a confidence level of $95 \%$ residual levels of TCDD in broiler chicken liver can be seen in Table 2 below:

The results showed that $750 \mathrm{mg}$ casein therapy from casein products of goat milk yogurt given for 21 consecutive days decreased the level of TCDD residues in 3 -wk-old broiler chicken liver exposed to TCDD $50 \mathrm{ng} / \mathrm{mL} / 1 \mathrm{~kg}$ of feed for $21 \mathrm{~d}$. This is done by TCDD exposure at $3 \mathrm{wk}$ because at that age broilers are can adapt, are strong, and no longer care to control the temperature and brooder, related for $21 \mathrm{~d}$ by adjusting the harvest time of broiler chickens, namely 5-6 wk of age. An increase in TCDD residue that occurs in the negative control to the positive control of the liver results in a buildup of toxins that are difficult to excrete because not to dissolve in polar solvents. TCDD is the compound most toxic member of dioxin from the planar class, halogenated by aromatic hydrocarbons. TCDD is a widespread environmental contaminant produced by various chemical reactions and combustion processes.

Table 2. Average TCDD Residue Levels of Broiler Liver Treated with $750 \mathrm{mg}$ Casein Tablet Made from Goat Milk Yogurt

\begin{tabular}{lccc}
\hline Treatment Group & $\begin{array}{c}\text { Residue Levels TCDD } \\
(\mathrm{mg} / \mathrm{L})(\mathrm{Mean} \pm \mathrm{SD})\end{array}$ & $\begin{array}{c}\text { Increased TCDD } \\
\text { Residue Levels }(\%)^{*}\end{array}$ & $\begin{array}{c}\text { Decreased in TCDD } \\
\text { Residue Levels }(\%)^{* *}\end{array}$ \\
\hline Negative Control & $0.1039 \pm 0.0102^{\mathrm{a}}$ & - & - \\
Positive Control & $0.1407 \pm 0.0224^{\mathrm{b}}$ & 26.15 & - \\
Therapeutic Group & $0.1326 \pm 0.0077^{\mathrm{b}}$ & - & 5.75 \\
\hline
\end{tabular}

Note: $* \%$ increase in levels of TCDD residues in the negative control of broilers obtained by comparison of the average levels of TCDD residues in positive control of broiler chickens. $* * \%$ decrease in TCDD residue levels in control of broiler chicken therapy obtained by comparison of the average levels of TCDD residue in positive control of broiler chickens. The different notation indicates a significantly different effect $(p<0.05)$.

Dioxin is a toxic compound and very stable against the degradation process by the environment and by biological processes so that it is persistent in the environment. Dioxins bind strongly to the organic matter in the environment and the can be found in the upper layers of the soil. Due to the lipophilic and hydrophobic nature of dioxin, it is difficult for the substance to be metabolized in the body. As a result, dioxin easily accumulates and biomagnification occurs through the food chain or food. Exposure to TCDD in humans and vertebrate animals is one of the risk factors for cancer, immune system disorders, reproductive disorders accompanied by abnormalities of fetal development, endocrine system disorders, damage to the liver, heart, and nervous system disorders. Exposure to TCDD in humans occurs through three main pathways, namely work accidental exposure and exposure to a contaminated environment.

The pathway for contaminants to enter the human body is through the gastrointestinal, dermal, and transpulmonary absorption. Exposure to humans most often is through the secondary pathway, namely through food. After experiencing absorption, TCDD in the 
circulation will bind to chylomicrons, lipoproteins, and other serum proteins, then quickly distributed to various organs. TCDD toxicity is not based on the number of exposures (rate of exposure) but depends on the body burden because of the long halflife of dioxin. The half-life of dioxin in mice is $12-31 \mathrm{~d}$, mice $11-24 \mathrm{~d}$, hamsters $11-15 \mathrm{~d}$, marmots 30-94 d, cattle 40-50 d, monkeys $391 \mathrm{~d}$, and in humans for $11 \mathrm{y}$. Dioxin toxicity is based on the total dioxin toxic equivalency (TEQ) approach that expresses the toxicity of pure TCDD material (Schecter et al., 2006; Van den Berg et al., 1994).

Dioxin pollution in food is still not getting much attention, especially in Indonesia. Very little information and data on pollution and the negative effects of dioxin. In a study conducted by Sani (2015) on dioxin residue levels using GC-MS as many as 50 samples consisting of 20 samples from SlaughterhousesYogyakarta, 15 samples from RPH-Central Java and 15 samples from RPH-East Nusa Tenggara.

The results of the analysis of the average total TCDD residue in samples from RPH-Yogyakarta reached $13,624.38 \mathrm{pg} / \mathrm{g}$ with a range of 4,496.66-20.642.40 pg/g higher than the samples from RPH-East Nusa Tenggara which reached $1,623.98 \mathrm{pg} / \mathrm{g}$ in the range of 0.83-6.471.07 pg/g. Total TCDD residues in samples from RPH-Yogyakarta reached
$54,497.52 \mathrm{pg} / \mathrm{g}$ and samples from RPH-East Nusa Tenggara reached 6,495.9 pg/g (Sani, 2015). The results showed that the TEQ value in broiler chicken samples far exceeded the maximum allowable TCDD residue. The standard for the maximum limit of dioxin contamination in food ingredients in force in Indonesia is set by the Food and Drug Monitoring Agency (BPOM). The maximum value of dioxin and furan contamination in processed food can be seen in the range of 3-4 pg/g.

\section{Effect of Casein Tablet Made from Goat Milk Yogurt on Malondialdehyde (MDA) Level in Broiler Liver Exposed to 2,3,7,8- Tetrachlorodibenzo-p-dioxin}

MDA is a product of lipid peroxidation by free radicals in the body. Detection of MDA levels generally uses serum or organs as samples. In this study, the liver is used as a determination of MDA levels because the liver has a detoxification function.

Toxic compounds that enter the body will undergo xenobiotic metabolic processes in the liver. MDA levels were measured using a complex reaction method between MDA and Thiobarbituric Acid (TBA). Measurements were made at a wavelength of $532 \mathrm{~nm}$. The results of making a standard curve obtained by the equation $\mathrm{y}=0.0025 \mathrm{x}+0.0138$ with a value of $\mathrm{R} 2=0.9889$. The MDA levels can be seen in Table 3 below:

Table 3. Average MDA Levels of Broiler Liver Treated with $750 \mathrm{mg}$ Casein Tablet from Made Goat Milk Yogurt

\begin{tabular}{lccc}
\hline Treatment Group & $\begin{array}{c}\text { MDA Levels }(\mu \mathrm{g} / \mathrm{mL}) \\
(\text { Mean } \pm \text { SD) }\end{array}$ & $\begin{array}{c}\text { Increased MDA } \\
\text { Levels }(\%)^{*}\end{array}$ & $\begin{array}{c}\text { Decreased MDA } \\
\text { Levels }(\%) * *\end{array}$ \\
\hline $\begin{array}{l}\text { Negative Control } \\
\text { Positive Control }\end{array}$ & $\begin{array}{c}26.8133 \pm 12.1363^{\mathrm{a}} \\
\text { Therapeutic Group }\end{array}$ & - & - \\
\hline Note: $* \%$ increase in MDA levels in the negative control of broiler chickens obtained a \\
comparison of the average MDA levels in positive control of broiler chickens. **\% \\
decrease in MDA levels in control of broiler chicken therapy obtained by comparison \\
of the average MDA levels of positive control of broiler chickens. The different notation
\end{tabular}


The results showed that the administration of $750 \mathrm{mg}$ casein therapy from casein tablets of goat milk yogurt to MDA levels in chicken livers exposed to TCDD for $21 \mathrm{~d}$ consecutive could reduce levels of MDA from increasing MDA levels without therapy. The presence of TCDD compounds that are exposed to broilers signifies as a source of free radicals that produce MDA levels as a benchmark for free radicals formed in the body of broilers. In the control liver therapy, there was a decrease in MDA levels from positive control which showed a decrease in MDA levels by $43.74 \%$ which was significantly significant $(\mathrm{p}<0.05)$ because it had a different notation between positive control and therapy that indicated the treatment results differed greatly or not. as homogeneous. Liver control of broiler chicken therapy obtained MDA levels of $28.54 \mu \mathrm{g} / \mathrm{mL}$ which was lower than the positive control that was equal to $50.74 \mu \mathrm{g} / \mathrm{mL}$. While the MDA levels in broiler chicken liver increased by $47.16 \%$ of the MDA levels of negative control liver that is $26.81 \mu \mathrm{g} / \mathrm{mL}$ lower than the positive controls that significantly affected ( $p$ $<0.05)$.

Exposure to TCDD increases the level of MDA in the liver. Padaga et.al., (2018) reported the that the antioxidant potential of goat milk yogurt tested against white rats (Rattus norvegicus) as a reprotoxic animal model exposed to TCDD showed a significant effect $(p<0.05)$ on serum SOD and MDA levels, testicular MDA and spermatozoa cell density due to exposure to TCDD at doses of $900 \mathrm{mg} / \mathrm{kg}$ body weight of goat milk yogurt (Padaga et al., 2018) casein supplementation of goat milk yogurt on dioxin intoxication with rat liver parameters influencing goat milk significantly $(p<0.05)$ to a decrease in the level of the enzyme y-glutamyl transferase (GGT) with an optimal dose of $600 \mathrm{mg} / \mathrm{kg} / \mathrm{d}$. Besides reducing the activity of antioxidant enzymes, such as glutathione (GSH), superoxide dismutase (SOD), glutathione peroxidase (GSH-Px), and catalase (CAT) (Setianingrum et al., 2019). TCDD compounds induce lipid peroxidation and weaken the antioxidant defense system in various organs (Triebig $e t$ al., 1998).

\section{Effect of Casein Tablet Made from Goat Milk Yogurt on Liver Histopathological Profile in Broiler Exposed to 2,3,7,8- Tetrachlorodibenzo-p-dioxin}

The liver in humans weighs about $1.5 \mathrm{~kg}$ which is the largest exocrine, gland functions as a producer of bile which breaks down fat and endocrine in all metabolic processes, both anabolism and catabolism such as amino acids, fats, and glucoses. Liver cells in protoplasm are nucleated and polyhedral cells that contain many enzymes. TCDD toxicity effects in animals can change the specific morphology that occurs due to hyperplasia and hypertrophy in parenchymal cells resulting in decreased liver function, decreased antioxidant enzyme activity with increased serum and liver damage (Türkez et al., 2013).

Histopathological assessment of the therapeutic effect of $750 \mathrm{mg}$ casein from casein tablets of goat milk yogurt exposed to TCDD in broiler chicken liver tissue was evaluated as in Figures $\mathbf{1}, \mathbf{2}$, and $\mathbf{3}$. Histopathological picture of broiler liver tissue negative control group in Figure 1 (A) contained cells normal hepatocytes $(\mathrm{NH})$, congestion in the central venous lumen $(\mathrm{CV})$, portal vein $(\mathrm{PV})$, and normal biliary tract (BD). (B) there are hepatocyte $(\mathrm{H})$ cells arranged radially from the central vein (CV).

Microscopic observations of the chicken liver tissue of the control group showed that the liver lobules were arranged radially from the central vein. The liver lobules appear separated by connective tissue. The portal area consists of a central vein, portal vein, and biliary duct which shows that the hepatocytes appear normal. In contrast to the positive control group that can be seen in Figure 2 below: 


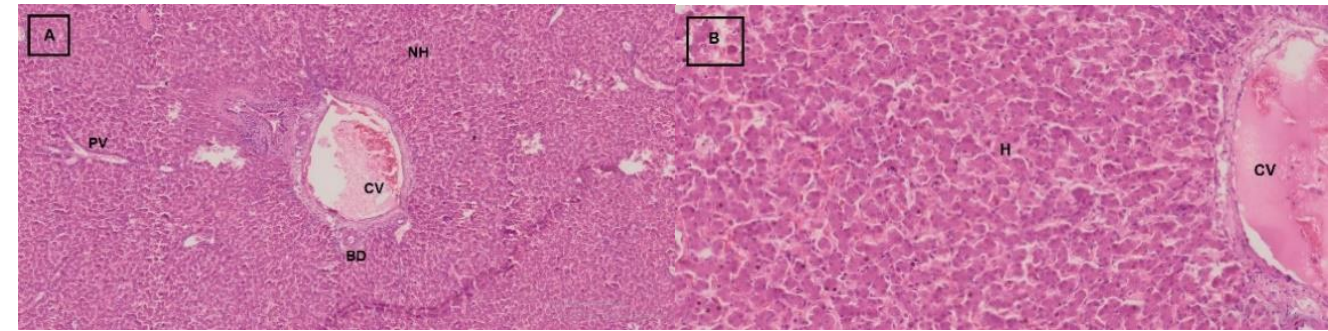

Figure 1. Results of Hematoxylin-Eosin Staining of Broiler Chicken Liver with $200 \times$ and 400× Magnification. (A.B) Negative Control Group.

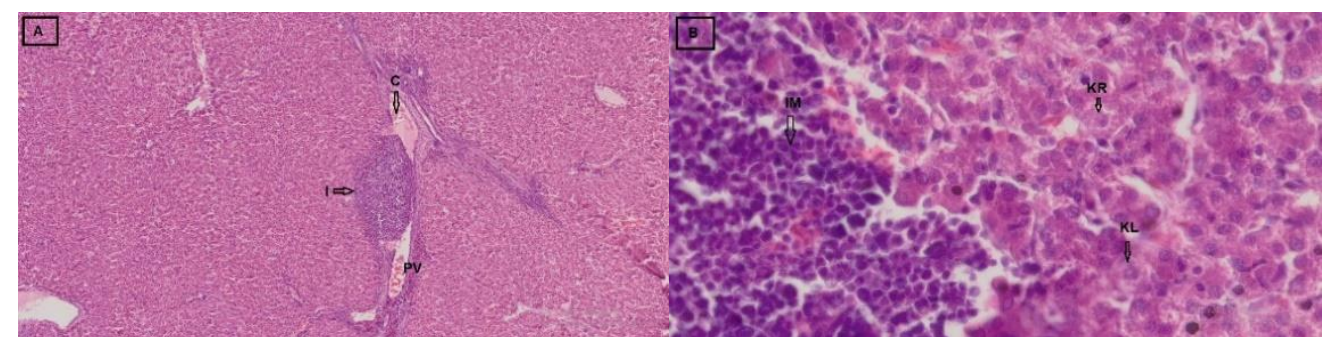

Figure 2. Results of Hematoxylin-Eosin Staining of Broiler Chicken Liver With 200× and $400 \times$ Magnification. (A.B). Positive Control Group.

The results of histopathology of chicken liver tissue in the positive control group showed (A) there was mononuclear cell (IM) infiltration around the portal vein $(\mathrm{PV})$ and congestion in the portal venous lumen (PV).

(B) there is the infiltration of leukocyte cells and hepatocytes undergo caryolysis and caryorexis. Histopathological microscopic observation of chicken liver in the positive control group showed that the liver had hepatotoxicity.
Irregular sinusoidal shape. The liver sinusoid has moderate congestion, infiltration of mononuclear cells around the portal vein. Central venous veins also dilate and hepatocytes from some liver lobules undergo changes in necrosis characterized by degeneration of the cytoplasm and cell nuclei undergoing caryolysis and caryorexis. While the picture of the therapeutic control group there is little improvement in tissue damage can be seen in Figure 3 below:

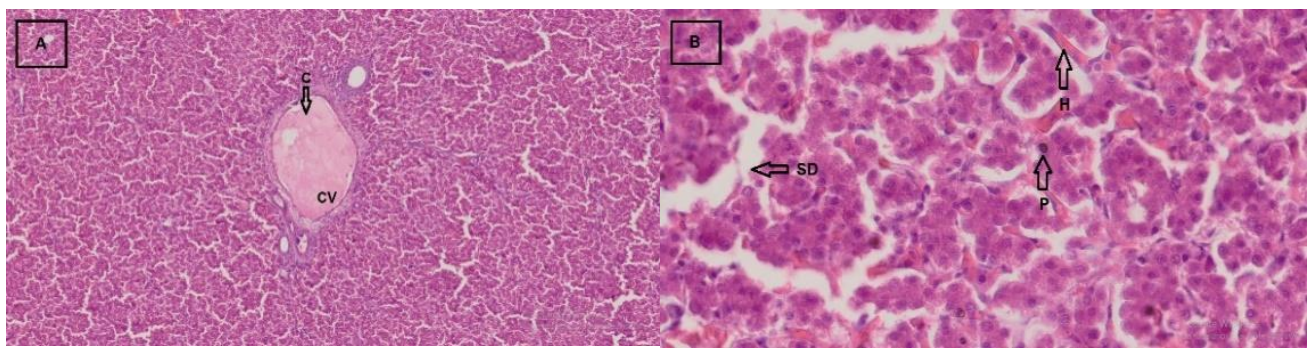

Figure 3. Results of Hematoxylin-Eosin Staining of Broiler Chicken Liver With 200× and $400 \times$ Magnification. (A.B). Therapeutic Control Group.

The results of the histopathological picture of broiler liver tissue in the therapeutic control group showed (A) there was congestion in the central venous lumen (CV). (B) sinusoid dilation (SD) occurs, hemorrhage $(\mathrm{H})$ in sinusoids and hepatocyte pyknosis occurs. Microscopic observation of histopathology in the chicken liver of the therapy group showed that there was congestion of the central venous lumen and sinusoid. Sinusoid shape looks irregular and has moderate dilatation. Some hepatocytes undergo pyknosis. Mononuclear (inflammatory) cells appear to be reduced 
compared to the positive dick group. Theoretically, the process of liver damage starts from the degeneration process shown by cell swelling.

Treatment with TCDD exposure seems to produce an extracellular fluid into large amounts of cytosol. One of the changes caused by toxic chemicals and can cause the formation of free radicals, it is a change in the characteristics of cells and cytoplasmic membranes in cellular components, such as mitochondria and lysosomes that are affected by lipid peroxidation (Karami et al., 2001). After damaging the cell membrane, toxic chemicals can also reach and destroy the cell nucleus, which causes abnormal cell structure and progresses to necrosis. Necrosis is degradation or irreversible cell disorganization or cell death as a lesion effect, signed by the apparent morphological transformation of the nucleus as pyknosis (solidified cell chromatin), caryoreksis (nucleus rupture) and caryolysis (nucleus disappears) (Ciftci et al., 2013).

Hepatocyte damage and oxidation stress due to TCDD induction have encouraged the development of various studies on active ingredients that are can protect hepatocytes against oxidative stress focused on antioxidants (Turkez and Geyikoglu, 2011). TCDD given in doses of 10 to $100 \mathrm{ng} / \mathrm{kg}$ body weight/day for thirteen weeks to female Sprague Dawly mice can cause liver mutases such as hepatocellular degeneration, inflammation, necrosis, vacolization of the cytoplasm, changes in shape, increased production of superoxide anions, lipids peroxidation, broken DNA stands, and decreased glutathione in brain and liver tissue. Oral administration of TCDD at a dose of $0.1 \mathrm{ng} / \mathrm{kg}$ body weight for twenty-seven days in the histopathological description of the liver is hepatocyte vacuolization, inflammation, and increased Kupffer, necrosis, and an increase in the amount of malondialdehyde (MDA) blood plasma (Hassoun et al. 2000).

\section{CONCLUSION}

Therapy with $750 \mathrm{mg}$ Casein tablets made from goat milk yogurt can prevent the increase of TCDD residual levels, malondialdehyde (MDA) levels and can prevent damage to the histopathological picture of broiler chicken liver tissue exposed to 2,3,7,8-Tetrachlorodibenzo-pdioxin (TCDD). So that it can be used as an antioxidant nutraceutical.

\section{REFERENCES}

Bamdad, F., Shin, S. H., Suh, J.-W., Nimalaratne, C., \& Sunwoo, H. (2017). Anti-inflammatory and antioxidant properties of casein hydrolysate produced using high hydrostatic pressure combined with proteolytic enzymes. Molecules, 22(4), 609. https://doi.org/10.3390/ molecules22040609

Binh, N. D., Oanh, N. T. K., \& Parkpian, P. (2014). Photodegradation of dioxin in contaminated soil in the presence of solvents and nanoscale $\mathrm{TiO} 2$ particles. Environmental Technology, 35(9), 1121-1132. https://doi.org/ 10.1080/09593330.2013.861873

Ciftci, O., Disli, O. M., \& Timurkaan, N. (2013). Protective effects of protocatechuic acid on TCDD-induced oxidative and histopathological damage in the heart tissue of rats. Toxicology and Industrial Health, 29(9), 806-811. https://doi.org/10.1177/074823371244 2735

Geronikaki, A., \& Gavalas, A. (2006). Antioxidants and inflammatory disease: synthetic and natural antioxidants with anti-inflammatory activity. Combinatorial Chemistry \& High Throughput Screening, 9(6), 425-442. https://doi.org/10.2174/138 620706777698481

Hassoun, E. A., Li, F., Abushaban, A., \& Stohs, S. J. (2000). The relative abilities of TCDD and its congeners to induce oxidative stress in the hepatic 
and brain tissues of rats after subchronic exposure. Toxicology, 145(2-3), 103-113. https://doi.org/10. 1016/S0300-483X(99)00221-8

Hayward, D. G., \& Bolger, P. M. (2005). Tetrachlorodibenzo-p-dioxin in baby food made from chicken produced before and after the termination of ball clay use in chicken feed in the United States. Environmental Research, 99(3), 307-313. https://doi.org/10.10 16/j.envres.2004.11.007

Indraningsih, \& Sani, Y. (2015). Detection of dioxins trichloro dibenzo-p-dioxins and trichloro dibenzofurans in beef with gas chromatography tandem mass spectrometry. Jurnal Ilmu Ternak Dan Veteriner, 19(4). https://doi.org/10.14 334/jitv.v19i4.1098

Kan, C. A., \& Meijer, G. A. L. (2007). The risk of contamination of food with toxic substances present in animal feed. Animal Feed Science and Technology, 133(1-2), 84-108. https://doi.org/10.1016/j.anifeedsci.2 006.08.005

Karami, M., Khansari, M. G., Rezayat, M., Zangi, M. B. M., Abdollahi, M., \& Sabzevari, O. (2001). Histopathological study of tcdd by isolated rat liver perfusion system. Medical Journal of The Islamic Republic Of Iran (MJIRI), 15(6), 55-60.

Neha, A., \& Tarun, G. (2012). Review on casein production and casein based nano-formulations. International Research Journal of Pharmacy, 3(1), 41-45.

Nuttall, S. L., Kendal, M. J., \& Martin, U. (1999). Antioxidant therapy for the prevention of cardiovascular disease. International Journal of Medicine, 92(5), 239-244. https://doi.org/10. 1093/qjmed/92.5.239

Padaga, M., Erika P. H, A., \& Irawan, M. (2018). Efek antioksidatif kasein yogurt susu kambing terhadap pencegahan reprotoksik pada hewan model rattus norvegicus yang dipapar 2, 3, 7, 8 Tetrachlorinedibenzo-P-
Dioksin (TCDD). Jurnal Ilmu Dan Teknologi Hasil Ternak, 13(2), 72-80. https://doi.org/10.21776/ub.jitek.2018 .013 .02 .1

Pemberthy, D., Quintero, A., Martrat, M. G., Parera, J., Ábalos, M., Abad, E., \& Villa, A. L. (2016). Polychlorinated dibenzo-p-dioxins, dibenzofurans and dioxin-like PCBs in commercialized food products from Colombia. Science of The Total Environment, 568, 11851191. https://doi.org/10.1016/j.scitote nv.2016.04.113

Schecter, A., Birnbaum, L., Ryan, J. J., \& Constable, J. D. (2006). Dioxins: An overview. Environmental Research, 101(3), 419-428. https://doi.org/10. 1016/j.envres.2005.12.003

Setianingrum, A., \& Padaga, M. C. (2019). Antioxidant activity of goat milk yogurt casein on dioxin intoxicated rat liver function. Journal Veterinary Biomedical and Clinical, 1(1), 26-32.

Singh, R. P., Chidambara Murthy, K. N., \& Jayaprakasha, G. K. (2002). Studies on the Antioxidant Activity of Pomegranate ( Punica granatum) Peel and Seed Extracts Using in Vitro Models. Journal of Agricultural and Food Chemistry, 50(1), 81-86. https://doi.org/10.1021/jf010865b

Swarayana, I. M. I., Sudira, I. W., \& Berata, I. K. (2012). Perubahan Histopatologi hati mencit (mus musculus) yang diberikan ekstrak daun ashitaba (Angelica keiskei). Buletin Veteriner Udayana, 4(2).

Triebig, G., Werle, E., Papke, O., Heim, G., Broding, C., \& Ludwig, H. (1998). Effects of dioxins and furans on liver enzymes, lipid parameters, and thyroid hormones in former thermal metal recycling workers. Environmental Health Perspectives, 106, 697. https://doi.org/10.2307/3433822

Turkez, H., \& Geyikoglu, F. (2011). The effect of laurel leaf extract against toxicity induced by $2,3,7,8$ Tetrachlorodibenzo-P-Dioxin in cultured rat hepatocytes. Archives of 
Industrial Hygiene and Toxicology, 62(4), 309-315. https://doi.org/10.24 78/10004-1254-62-2011-2118

Türkez, H., Yousef, M. I., \& Geyikoglu, F. (2010). Propolis prevents aluminiuminduced genetic and hepatic damages in rat liver. Food and Chemical Toxicology, 48(10), 2741-2746. https: //doi.org/10.1016/j.fct.2010.06.049

Van den Berg, M., De Jongh, J., Poiger, H., \& Olson, J. R. (1994). The toxicokinetics and metabolism of Polychlorinated Dibenzo- $p$-Dioxins (PCDDs) and Dibenzofurans (PCDFs) and their relevance for Toxicity. Critical Reviews in Toxicology, 24(1), 1-74. https://doi.org/10.3109/104084 49409017919

Verruck, S., Dantas, A., \& Prudencio, E. S. (2019). Functionality of the components from goat's milk, recent advances for functional dairy products development and its implications on human health. Journal of Functional Foods, 52, 243-257. https://doi.org/ 10.1016/j.jff.2018.11.017 